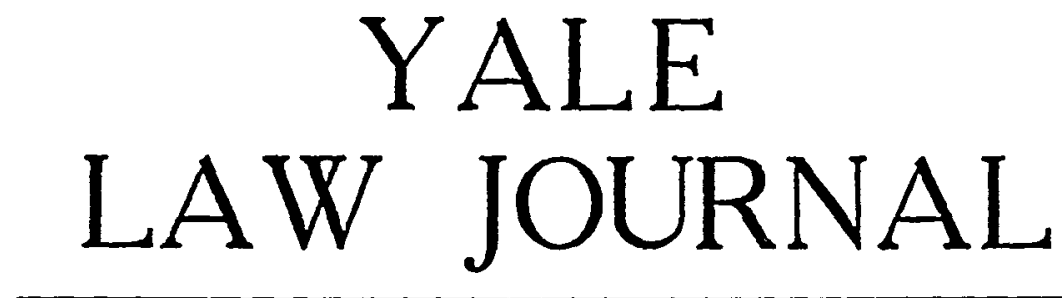

Vol, XXXVII

NOVEMBER, 1927

No. 1

\title{
ENGLISH PROPERTY REFORM AND ITS AMERICAN ASPECTS
}

\section{PERCY BORDWELL}

"In England men are rated by their income, in the United States by their principal." Such was the remark of an American officer returning from the World War. In that remark lies the explanation of much of the difference between property conditions in England and in the United States. Settled property is the rule in England. It is the exception in the United States. It is traditional for the Englishman to make provision for the marriage and the fruits of the marriage before the marriage takes place. To the romantic American the adherence to this custom in international marriages has seemed coldblooded and calculating. On the other hand it has been said of the Englishman that to him it would seem almost as immoral to do away with the marriage settlement as with marriage itself." And when the oldest son attains his majority or wishes to marry, provision is made for the third generation by means of a settlement. This is so much a part of English life that those who shaped the recent reform of property law in England could not have changed it if they would. Nor would they if they could. The strict family settlement may disappear and the trust for sale take its place, but in the one form or the other settled property will continue to characterize English life.

The great problem in England has been how to reconcile this provision for the needs of future generations with free trade in land. Prior to the Settled Land Act of 1882,- the alienability of settled land was possible through the grant of express powers to the life tenant. That act conferred such powers on him as 2

1 See the statement by Osborne Morgan quoted in UNDERInL, A CENTURY OF LAW REFORII (1901) 290. Mir. MIorgan was the chairman of the Select Committee of 1878-9 on Land Titles and Transfer.

2 (1882) 45 \& 46 Vict. c. 38. 
matter of law ${ }^{3}$ and safeguarded the interests of others under the settlement by requiring the purchase money to be paid to the trustees of the settlement or into court, ${ }^{4}$ and imposing the limitations of the settlement on the proceeds. ${ }^{\circ}$ A great measure of free trade was thus secured. The recent reform in England was the logical outcome of that step. ${ }^{6}$ The new Property Acts have made possible the free alienability of land to a remarkable extent ${ }^{7}$ and at the same time retained the main features of the old settlement. In doing this, however, they have shifted from powers to estates as the basis for conveyancing. ${ }^{8}$ Instead of the beneficial life tenant having a power to convey the fee, he now has the legal fee $^{\circ}$ and sells as the "estate owner" of that fee. ${ }^{10}$ This change, from powers to estates as the basis for conveyancing, was one of the high spots of the reform. It presented many practical difficulties. ${ }^{12}$ These difficulties were not lessened by the fact that the new acts include under the technical designation of settlements and settled land even more than had been included by the Land Transfer Act of 1882.12

The conveyancing device, other than the settlement, used to secure free trade in land by those who shaped the reform legislation in England was the personalty trust or the trust for sale. ${ }^{13}$ This has been in use for many years. One of its advantages was that by means of two deeds, a vesting deed and a trust deed, the

\footnotetext{
$3 \S 3$.

$4 \S 22(1)$.

$5 \S 22(5), 24$.

- UNDERHILL, A ConCise EXPLANation of Lord Birkenhead's ACT (1922) 31.

7 "The idea is always to have a tenant or tenants in fee simple absolute in possession who will be able to convey the land." Guide TO THE NEW Property Statutes by the Editors of Law Notes (1925) 4.

8 "Estates (as opposed to powers) are to be the basis of conveyancing." Memorandum by Mr. B. L. Cherry on The Principles and Objects of the Law of Property Bill, Fourth Report of the Acquisition and Valuation of LaND Committee (1919) Appendix IV, 44.

${ }^{9}$ (1925) 15 Geo. V, c. $18, \S \S 4(2), 5,6,7$.

10 (1925) 15 Geo. V, c. $20, \S 1$, (4) (7).

11 Not the least of these has been as to the devolution of the beneficial lifo tenant's legal fee. See Lightwood, Devolution of Settled Land (1927) 63 Law Journat 120, 152, 176; ibid. Real Estate and Personal Representatives, ibid. 202.

12 Compare (1925) 15 Geo. V, c. $18, \S 1$, with (1882) $45 \& 46$ Vict. c. 38, $\S 2$. The principal new statutory settlements are "where a married woman is entitled in fee simple, subject to a restraint on anticipation, and whero property is subject to any family charge, whether by way of rent charge or capital charge." Lightwood, The New Law of Settled Land (1925) 60 LAW JOURNAT 679. See also op. cit. supra note 7, at 223.

13 (1925) 15 Geo. V, c. $20, \S \S 2$ (1) (ii); 2 (2) as amended by (1926) 16 \& 17 Geo. V, c. 11, Schedule; c. 3 (1) (b) ; c. 22-23.
} 
details of the trust were kept off the title. ${ }^{14}$ By the reform legislation this scheme of two deeds was extended to settlements. ${ }^{25}$ The reason why the trust for sale was called a personalty trust was that an imperative duty to sell was imposed on the trustees and this worked an equitable conversion of the beneficiary's interests into personalty. The trust was for the purpose of sale and the beneficiary's interest was in the proceeds. The purchaser was not concerned with the equities under the trust. Equities prior to the trust of which the purchaser had notice were binding on him. ${ }^{16}$ The new legislation preserves the trust for sale and provides that where the trustee is a trust corporation or where there are two trustees approved by the court, not only may the equities under the trust be gotten rid of, but prior equities may be overreached.17 A similar overreaching effect is given to settlements. ${ }^{18}$ Certain equities, such as equitable mortgages protected by title deeds, equitable restrictions, and agreements to convey, are excepted from this overreaching effect, ${ }^{10}$ but, except in the case of equitable mortgages protected by title deeds, these must be registered as land charges ${ }^{20}$ or they are not. binding even on a purchaser with notice.21 At the same time the number of trusts for sale is increased by the creation of statutory trusts for sale, the most notable of which takes the place of the common law tenancy in common.22

With two important exceptions, all settlements must be made by way of trust. ${ }^{23}$ Between them, settlements and trusts for

14 Lightwood, op. cit. supra note 12, at 653; ibid. The Ncu Conveyancing: A Review (1926) 62 LAW JoURnal 66, 67.

15 (1925) 15 Geo. V, c. 18, § 4.

16 Lightwood, The New Conveyancing: A Revicw (1926) 62 Luw Jour:ar. 67; ibid. Binding Tmusts for Sale (1926) 61 ibid. 554.

17 (1926) 16 \& 17 Geo. V, c. 11, Schedule, Amendment to Law or PropERTY ACr (1925) 15 Geo. V, c. 20, § 2 (2).

18 (1925) 15 Geo. V, c. 18, § 72 (3) b; see Bordwell, Propcrty Reform in England (1925) 11 IOWA L. REv. 1, 16.

${ }^{10}$ (1925) 15 Geo. V, c. 18, §§ 21 (2), 72 (2) (iii) (b), (B); (1025) 15

Geo. V, c. $20, \S 2(2)$.

20 (1925) 15 Geo. V, c. $22, \S 10$ (1) class C, class D, $\$ 13$ (2).

${ }^{21}$ (1925) 15 Geo. V, c. 20, \& 199 (1) (i). Mr. Lightwood raises the question whether this section and section 13 of the LAND Cranges ACr (192-j) $15 \mathrm{Geo} . \mathrm{V}, \mathrm{c} .22$, cited in the preceding note, will be given the drastic efret indicated above, but admits that no one would wish his own client involved in it. Lightwood, The Registration of Restrictive Corronnts (1027) $6:$ LAW JoURNaI 28. The requirement of registration "before the completing of the purchase" even though there be actual notice made necessary section 4 of the LAW of Property (AMIENDMENT) ACT (1926) $10 \& 17$ Geo. V, c. 11. 22 (1925) 15 Geo. V, c. $20, \S \S 34,35$.

23 (1925) 15 Geo. V, c. 18, $\$ 1$. The exceptions are (1) land limited to a married woman with a restraint on anticipation ( 1 (1) (iv) ) and (2) land subject to a family charge (\$ 1 (1) (v)). 
sale seem to cover the whole field of express trusts as well as the artificial settlements and trusts for sale created by statute. ${ }^{24}$ They. are also made mutually exclusive. ${ }^{25}$ If the trust is not a trust for sale it is a settlement: A trust for sale is officially defined as an immediate binding trust for sale.20 The typical settlement is where there are successive interests. The only legal estates left that can be created or conveyed at law are the estate in fee simple absolute in possession, and the term of years absolute. ${ }^{27}$ All other estates take effect as equitable interests. ${ }^{28}$ Not properly estates, but called such in the statute, ${ }^{z 0}$ are a limited number of interests such as easements in fee and charges by way of legal mortgage which are cognizable at law. ${ }^{30}$

It is through these two devices, then, the settlement and the trust for sale, that free trade in land has been secured without sacrificing the interests of future generations. Future interests and undivided shares, as well as the interests of infants, ${ }^{31}$ are changed into equitable interests and protected behind the screen of the settlement or trust for sale without interfering with the saleability of the land. But it has not been all clear sailing.

The men who shaped this rather elaborate machinery of the "curtain scheme" were eminent conveyancers, accustomed to the handling of large estates. They were merely perfecting and extending a system already familiar to them. In the attempt to make the system universal, however, they were extending it to situations where it was not already familiar, where it was not particularly adaptable and where it might work great hardship. These difficulties have been accentuated in the transition period. As a matter of fact the attempt to apply the new scheme as of Jan. 1, 1926 to land held subject to family charges broke down ${ }^{\text {s2 }}$ and a settlement which ceased to be such before any transfer was

24 See Lightwood, Trusts for Sale and Settlements (1926) 62 LAw JourNAL 344 .

25 Ibid; LAW of Property (AMENDMeNT) AcT, (1926) 16 \& 17 Geo. V, c. 11, Schedule, Amendment to SeTTLED LAND ACT, 1925, § 1.

26 (1925) 15 Geo. V, c. $20 \S 205$ (1) (xxix). For a discussion of this definition and of the decision in Re Leigh's Settled Estates [1926] Ch. 852;

see Lightwood, Binding Trusts for Sale (1926) 61 LAW JourNar 554:

ibid. Trusts for Sale and Settlements (1926) 62 ibid. 344, 368, 390.

27 (1925) 15 Geo. V, c. $20, \S 1$ (1).

28 Ibid. $\$ 1$ (3).

29 Ibid. $\$ 1$ (4).

30 Ibid. \$ 1 (2) (3).

31 Ibid. $\$ 1(6)$.

32 LaW of Property (AMendment). Act (1926) $16 \& 17$ Geo. V, c. 11,

$\S 1$. The need for this amendment was the main cause of the act. Seo Lightwood, The Proposed Amendments of the Law of Property Acts (1926) 61 IAW JOURNAL 501, 502. 
made was held not to come within the Settled Land Act, 1925, although it had not ceased to be a settlement until after January $1,1926.33$ In the case of small estates the hardship is likely to be very great ${ }^{34}$ and it seems a needless burden, if the purchaser demands it, for the vendor to have to go to the expense of a special settlement or trust for sale to get rid of some equity notwithstanding the holder of the equity is willing to concur in the sale..$^{35}$ And in the case of ordinary settled land the requirement of a special probate, ${ }^{30}$ where formerly land passed automatically from the life tenant to the remainderman, would seem a burden disproportionate to any advantage to be gained. ${ }^{\text {sr }}$ Nor, as pointed out by the commitfee of the Conveyancer's Institute in 1920, 33 is it apparent that conveyancing has been simplified. Abstracts have been shortened by the removal of the trusts from the title, but an extremely artificial system has taken the place of what now seems to some to have been a comparatively natural and simple one. ${ }^{39}$ There has been a tendency, so notable for a hundred years under the New York Revised Statutes, to a lifeless resort to the command of the statute with a disregard of principle and common sense. ${ }^{10}$ Conveyancing has, if anything, become more technical and more expensive. ${ }^{11}$

To what, if any, extent the "curtain scheme" could be transplanted to this country is a question. The safe prediction would seem to be that if it were, no attempt would be made to include in the transplanting the settlement scheme of the Settled Land Acts. The strict settlement and the Settled Land Acts have been exclusively English 12 and, even in England, so discerning a critic

${ }^{33}$ Re Alefounder's Will Trusts (1927) W'kly Notes 32; see Lightwood, Settled Land Act, 1925, §13 (1927) 63 Law JounNsL 96; ibid. The Relcase of Family Charges (1926) 62 ibid. 442, 465.

${ }^{34}$ See Lightwood, Section 13 and Vesting Decds (1926) 61 Law Jounsar 530; ibid. The New Conveyancing: A Rcvicw (1926) 62 ibid. 67, 132; ibid. Real Estate and Personal Representatives (1927) 63 ibid. 202.

35 (1925) 15 Geo. V, c. 20, § 42 . See Lightwood, Trusts for Sale and Settlements (1926) 62 LAW JournaL 368.

${ }^{36}$ (1925) $15 \mathrm{Geo} . \mathrm{V}, \mathrm{c} .23, \S 22$. See Lightwood, Dcvolution of Settled Land (1927) 63 Law JourNaI 120, 152, 176.

${ }^{37}$ See ibid. Real Estate and Personal Represcntatives (1927) 63 ibid. 202. 38 (1920) 64 Sor. J. 741.

39 See Lightwood, The New Convcyancing Difficultics (1926) $61 \mathrm{Luw}$ JourNaL 166. MIr. T. Cyprian Williams is evidently of the same opinion as when he participated in the report of the committee of the Institute. Sce Williams, Searches by MLortgages on Repayment (1926) 61 ibid. 48S. See also the remarks of MIr. Coley, President of the Law Society, (1926) 62 itid. 211.

${ }^{40}$ Lightwood, The New Conveyancing: A Review, ibid. 44; ibid. Trusts for Sale and Settlements, ibid. 368.

41 Ibid. The New Conveyancing: A Review, ibid. 131, 132. 
as Mr. Lightwood ${ }^{43}$ would not be surprised "if in a few year's strick settlements disappear and trusts for sale hold the field." He says that

"it is a matter of common remark that the difficulties that have arisen in the working of the Property Acts have been largely concerned with settled land and these would all have been avoided if realty settlements had been dropped, and all settlements had been required to be made as personalty settlements; that is, by a conveyance in trust for sale with a separate deed declaring the trusts of the proceeds of the sale and of the income till sale."

The reason why this was not done, he thinks, was that

"there was the choice of placing the legal estate in the trustees and making them the ostensible owners, or of placing it in the tenant for life, and in deference to the owners of large estates, the latter course was chosen."

But "so" little do the dukes appreciate the prestige conferred upon them that they are, I understand, tumbling over each other's heels in their anxiety to abandon their role as landowners, and assume the quite undignified position of directors of estates companies."

At any rate neither the strict family settlement nor the scheme of the Settled Land Acts is for the United States.

On the other hand the trust for sale is not unknown in the United States and might with advantage be used much more than it is. ${ }^{44}$ However, there does not seem to be any call for giving it the extraordinary overreaching effect now given to it in England, nor does there seem to be any compelling reason for putting limited and future interests in land and undivided shares behind the screen it might afford. Putting them behind such a screen would be one way of assimilating the law of land to that of personalty and eliminating some of the chaos of our present law of future interests. It would also transfer to equity even more of the law with regard to land titles than is there at present, and this would be an advantage. The purchaser would be more certain of his title. Land would be more saleable. But it would be revolution, not evolution as in England. That is why the curtain scheme has so puzzled our lawyers. Even in England so many

42 Hogg, Property Law Reform at Home and Overseas, (1920) 64 Sot. J. 405, 407. "The provisions about settled land ... probably have no counterpart in the jurisprudence of any other civilized country." Lightwood, Trusts for Sale and Settlements (1926) 62 LAW JouRNaL 344.

43 Ibid.

44 For an argument in favor of the increased use of the conveyancing trust which, however, is to be distinguished from the trust for sale, see Bogert, Trusts and Escrows in Credit Conveyancing (1927) 21 ILL. L. REv. 655. 
equitable interests were finally required to be registered as land charges that it was said that "what the Acts really do is to compel equitable interests to come out into the open rather than to 'curtain' them behind the legal estate." 45 In the United States not only equitable interests, but legal interests as veell, are thus compelled to come out into the open through the universality of the registration of deeds. Equitable interests in land are as well protected as legal interests and there does not seem to be any feeling that either should be sacrified to the buyer.

In truth, the curtain scheme in England evolved from the realty and personalty settlements which were the stock in trade of the conveyancers. Neither is a tool ready to hand in the United States. To use either to shape property reform here would mean that the difficulties that have been encountered in England would be increased many fold. In England it was a question of extending the bounds of an already existing system. In the United States it would be a question of introducing the system. Moreover, from its immovable character, there is not the same need of a trustee in the case of land that there is in the case of personalty, and to require all life estates and all undivided shares to be put in trust would be a great burden. There would be less hardship in the case of the land of infants.

That a change would be revolutionary, however, is not an unanswerable argument against it. There is call for property reform in the United States and while there would seem to be no place for the curtain scheme with its overrenching of prior equities, a strong argument could be made for the abolition of the law of estates and the putting of partial interests in trust. It would seem to be the only alternative to a modernized law of estates.

Hardly less conspicuous in the reform than the curtain seheme was the abolition of the copyhold ${ }^{45}$ and the changes in the lav of intestate succession. ${ }^{47}$ Happily, the copyhold has never existed in the United States, ${ }^{15}$ and the old common law canons of descent

\footnotetext{
15 Op. cit. supra note 7, at vi.

\$6 LAw of Property ACT, (1922) $12 \& 13$ Geo. V, c. 16, \& 128, 12th Schcdule, $\$ 1$ (a).

17 (1925) $15 \mathrm{Geo} . \mathrm{V}$, c. $23, \S \S 45-52$. The most striking change is the abolition of collateral primogeniture. The INHenisusce ACr, 1898, "Temains in force for the purpose (so far as applicable) of ascertaining the devolution of entailed interests as equitable interests, and of ascertaining the persons who are to take equitable interests as heirs by purchase, but in other respects ceases to apply (save in the case of a lunatic or dorcetive provided for by the principal Act) on intestacies." (1925) 15 Gco. V, c. 5, Schedule 9. As to the inheritance of the fee tail, sce (1925) $15 \mathrm{Gco} . V$, c. 20, $\S 130$ (4).

48 I STORY, CoNSTitution, $\$ 172$.
} 
have long been obsolete. ${ }^{40}$ There is much in the new law of succession, however, that is worthy of study. The assimilation of the devolution of real property to that of personal property so that the land passes to the permanent representative in the same way as chattels, dates back to the Land Transfer Act of 1897. . $^{40 a}$ This reform, or something approaching it, has been adopted in many of the states ${ }^{40 b}$ and has much to commend it. It greatly simplifies the proof of title. The great favor shown the spouses in the new acts ${ }^{50}$ is of great interest as is also the exclusion from intestate succession of those beyond first cousins. ${ }^{.1}$ Other changes of a local rather than a comparative interest are the changes made in land registration ${ }^{52}$ and the change from the old common law mortgage to mortgage by long terms for years..$^{63}$ Provision, however, is made for mortgages by way of land charges, ${ }^{54}$ although it is doubtful to what extent these will be used. .55

Less conspicuous than many of the foregoing changes, but yet of interest to the real property lawyer, are numerous incidental reforms. It is these aspects of the English reform with which this article is primarily concerned. Some of these reforms were incident to the main reforms though not dependant on them. Others were suggested because reform was in the air. Those who shaped the new legislation were conveyancers of large experience and adaptable minds. ${ }^{5 \tau}$ They were not committed to the

494 KENT, Comm.* 374. Primogeniture never had any place, except as to entailed estates, in Pennsylvania and the New England colonies other than Rhode Island; nor in the other colonies did it long survive their independence. Morris, Primogeniture and Entailed Estates (1927) 27 CoL. L. Rev. 24-25. It is said that it still survives as to entails in Massachusetts and Maine. Ibid. 27.

49a (1897) 60 \& 61 Vict. c. 65 , pt. I. This has now been superseded by (1925) 15 Geo. V, c. 23 , pt. I.

19b WOERNER, AMr. LAW OF ADMINISTRation (3rd ed. 1923) § 337.

${ }^{50}$ In intestacy the surviving husband or wife (with or without issue) is entitled to a prior charge of $\$ 1000$. (1925) 15 Geo. V, c. $23, \S 46$ (1) (i). According to the statistics on which the legislation was based this means that $98 \%$ of intestate estates will go in toto to the surviving spouse. $154 \mathrm{H}$. C. Deb. 5 s. 99 .

51 (1925) 15 Geo. V, c. $23, \S \S 46$ (1) (v), 47 (3).

52 (1925) $15 \mathrm{Geo}$. V, c. 21 . For a summary of the changes, see op. cit. supra note 7, at 353-370. See also Lightwood, The Changes in the Registration of Title (1925) 60 LAW JOURNAI 1000, 1020; ibid. Registration of Title and the Legal Estate (1926) 62 ibid. 298.

53 (1925). 15 Geo. V, c. $20, \S \S 85,86$.

51 Ibid. $\$ \S 1$ (2) (c), 85, 87.

55 Lightwood, The New Conveyancing: A Review (1926) 62 LAw JourNaL 45. But see Topham, The Law of Property Acts (1926) 61 ibid. 126.

56 For a more extensive treatment of the main features of the reform, see Bordwell, op. cit. supra note 18, and for the repeal of the Statute of Uses, see Bordwell, The Repeal of the Statute of Uses (1926) 39 HAnv. L. REV. 466. 
subtleties of the schools. To them the jurisprudence of conceptions meant little. They were pragmatists. And if a change seemed to offer a better working basis than the rule in force they adopted it without much hesitation. In many respects these minor changes are of more direct application to conditions in the United States than the more conspicuous reforms.

\section{THE AROLITION OF THE INTERESSE TERMINI}

One of the anomalies of the law of property has been the interesse termini. Under the common law of Littleton's time the lessee, even prior to entry, had a "right presently to have the tenements according to the form of the lease" under which he might enter after the death of the lessor. There was no such survival where a deed of feoffment was given with a letter of attorney to deliver seisin. ${ }^{5 s}$ But as the lessee prior to entry did not have possession, no release could be made to him. 59 He was not yet tenant of the term. ${ }^{\text {co }}$ But he might enter when he would by force of the lease. 61 There is nothing in Littleton to indicate that this right which the lessee had before entry was transmissable. If it were not transmissable already, however, Coke made it so, for he declared that if the lessee died before entry his executors or administrators might enter, ${ }^{62}$ and that the right prior to entry was not "a naked right for then he could not grant it over" 63 whereas this interesse tcrmini, as he called it, was assignable. ${ }^{64}$ So this interesse tcrmini was property and not a mere right or chose in action, but yet not an estate. Moreover it was a legal right or interest and not a use. Coke was expounding law, not equity.

In view of the legal character of the right of the lessee for years before entry, the applicability of the Strtute of Uses to leases for years was not obvious. And the first application of the statute to leases was made, not to avoid entry but to avoid attornment in a lease of the reversion..$^{65}$ This Colie heartily subscribed to. ${ }^{66}$ Whether he would have taken the further step

57 "I may say that no one had a hand in the matter who was not either a leading conveyancer or a Parliamentary draftsman, or a sound practical lawyer." Lightwood, The Difficulties in the Property Acts (1926) $62 \mathrm{LaW}$ JOURNAL 210.

5s LITT. TEN. § $* 66$.

59 Ibid. $\$ 459$.

60 Ibid. $\$ 58$.

61 Ibid. $\$ 59$.

62 Co. LITT. $* 46 \mathrm{~b}$.

${ }^{63} \mathrm{Ibid.} \approx 270 \mathrm{~b}$.

64 Ibid. *46b, $* 270 \mathrm{a}$, b.

es Sir Rowland Heyward's Case, 2 Co. 35 (1595); Fox's Case, 8 Co. 98 (1610).

${ }_{68}$ Ibid. 
of resorting to the Statute to avoid the necessity of an entry to enable a release to be made to a lessee is doubtful, for he suggests nothing of the kind in his Commentaries. If a lease could operate as a bargain and sale to raise a use for one purpose, however, it was natural that it should be allowed to operate as such for other purposes and in the case of Lutwich v. Milton, decided in $1620,{ }^{67}$ the lease was held to operate as a bargain and sale so as to allow a release to be made to the lessee without actual entry. Hence followed the lease and release as the common method of transferring land in England for over two hundred years.

The theory' of the early cases was that if a lease satisfied the requirements of a bargain and sale then, it was at the election of the lessee to treat it as such or as a common law lease. ${ }^{68}$ And in Barker $v$. Keete, decided in 1678,60 the requirements for a bargain and sale were reduced to a minimum. The reservation of even a nominal rent was held sufficient, though there was no express word of bargain and sale or of consideration in the lease. The majority of the court in that case also held that the lease might operate as a bargain and sale although there was no evidence in the lease that the lessor intended it to operate as such. North C. J., however, differed from the rest of the court on this point and, apparently from abundant caution, conveyancers got into the habit of inserting in the lease a statement that it was made to the intent that thereby, and by the Statute of Uses, the lessee might be capable of a release. ${ }^{70}$ The authority of Barlcer $v$. Keete that such a statement was unnecessary seems never to have been shaken, ${ }^{71}$ but this practice of an express reference to the Statute of Uses in the lease, when used with the release as a conveyance, seems to have given an impression that"leases which contain no such express reference to the Statute operate as at common law. This impression that the average lease operates as at common law, unaffected by the Statute of Uses, was strengthened by Coke's omission to notice any effect of the Statute of Uses on the necessity of an actual entry and by his keeping alive the memory of the common law doctrine by his phrase interesse termini. ${ }^{72}$

67 Cro. Jac. 604 (1620).

68 See cases cited supra note 65. See also Miller v. Green, 8 Bing. 92, 106 (1831), and Mann, Crossman \& Paulin v. Land Registry [1918] 1 Ch. 202, 207.

68 Freem. 249 (1678).

70 Butler's Note 231 (1) VI 2, to Co. LITT. *271b.

712 PReston, Conveyancing (1819-25) 389. See also as to the sufficiency of a nominal consideration, $i b i d .373$, and as to words of bargain and sale not being necessary, ibid. 377 .

72 Coke borrowed this phrase from the old pleadings. He says: "Interest. Interesse is vulgarly taken for a terme or chattle reall, and more particu- 
In so far as the phrase interesse termini has stood for the need of actual entry, its tendency has been reactionary. In so far as it has stood for an interest that was grantable and therefore a property interest without entry, it has been in line with modern progress which has tended toward the transferability of nonpossessory rights. The anomaly of the intcresse termini was that it went part way without going the whole way. The principal resort to the doctrine of interesse termini in recent years has been to it on its progressive side as recognizing a property interest prior to entry. However, its reactionary aspect, with its stress on the importance of an actual entry, has been far the more conspicuous. This reactionary side of the doctrine has in fact been so conspicuous that quite commonly it has been treated as the whole doctrine, as if there were no other side. This was evidently so in the recent property reform. The doctrine of interesse termini was abolished ${ }^{73}$ but what the drafters really meant is shown in the next section which gives full legal effect to terms of years without actual entry. ${ }^{74}$ This does not necessarily mean that the drafters thought the actual entry still had significance, ${ }^{75}$ but rather that they were afraid that the repeal of the Statute of Uses ${ }^{\text {is }}$ might be considered to have revived the old law.

Only in one particular does the reactionary side of the doctrine of interesse termini seem to have survived to modern times in England, and that is in connection with future leases. At a time when the old common law of merger still retained its importance it was said that an interesse termini would neither cause nor prevent a merger:"7T This was said primarily with the future lease in mind, and resulted from the premise that an interesse termini was not an estate, ${ }^{78}$ whereas the law of mergers had only to do with estates. ${ }^{73}$ Merger could, however, apply to estates for years ${ }^{80}$ although the authorities were ancient ${ }^{82}$ and the law most speculative. Coke denied the application of the law of merger

larly for a future tearme; in which case it is said in pleading, that he is possessed de interesse termini."

73 (1925) 15 Geo. V, c. 20, § 149 (1).

iะ Ibid. \& 149 (2).

i5 In Mann, Crossman \& Paulin v. Land Registry, supra note 68, at 207, Neville J. said:- "I do not feel prepared to assert as law that a lease in futuro must be accompanied or followed by possession to malie it complete"

76 (1925) 15 Geo. V, c. 20 \$ (10), § 207, 7th Schedule.

77 Preston, op. cit. supra note 71 , at 207.

782 ibid. 215.

893 ibid. 55

so Ibid. 182.

s1 Hughes v. Robotham, Cro. Eliz. 302 (1593), seems to have bsen the leading case. 
to estates for years altogether ${ }^{82}$ as did Sheppard's Touchstone. ${ }^{83}$ Coke said :-

"If a man makes a lease for ten years, the remainder for twenty years, he in the remainder releaseth all his right to the lessee, he shall have an estate for thirty years; for one chattle cannot drowne another, and yeares cannot be consumed in yeares." 84

If there had been a technical merger, the ten year term would have been extinguished and only the twenty year term left. ${ }^{\mathrm{s}}$ This would clearly have been a very undesirable result ${ }^{80}$ and a similar result to Coke's was reached by Preston and others through calling the second term an interesse termini, since the interesse termini would not cause a merger. ${ }^{87}$ The logical result of Preston's opinion 'was the decision in Lewis v. Baker ${ }^{88}$ where a tenant entered into an agreement for a new lease for seventythree years to commence on the date of the expiration of the original lease. His old term had only a few months to run. He let the premises for twenty-one years and the court held that even though the agreement had been a formal lease it could have operated only as an interesse termini during the continuation of the old lease, that the underlease for twenty-one years was therefore just as absolute an assignment of his old lease as though no new lease had been granted him, and that therefore during the old lease he was an assignor and not a landlord and had no right to distrain. Under Coke's view the opposite result would have been reached. ${ }^{89}$ Perhaps Coke was wrong in saying that the tenant would have had an estate for the combined number of years, for the two leases might have been very different in their character, but the continued right to possession for the combined number of years whether under one lease or two, would seem to have been

82 See infra note 84.

${ }^{83}$ At $* 324$. The passage from Sheppard is quoted in 3 Preston, op. cit. supra note 71, at 183 . It follows Coke.

84 Co. LiTT. *273b.

85 See 3 Preston, op. cit. supra note 71, at 218.

86 So Preston admits. He says:- "As far as good reason and sense ought to prevail, and technical rules be exploded, it seems to be reasonable, that the assignee of two several and successive terms, one in possession and tho other in remainder, should be entitled to hold the possession for both theso terms, since from the nature of these interests, there is not any incompatibility between them, and the time of one estate is quite distinct from tho time of the other." Ibid. 202.

87 Ibid. 218.

88 [1905] 1 Ch. 46.

89 Lewis v. Baker did not involve a term limited by way of remainder, but for the doctrine of interesse termini, Coke's view would have been as applicable to a reversionary lease, as in Lewis v. Baker, as to a term limited by way of remainder.

${ }^{\circ 0} 3$ PRESTON, op. cit. supra note 71, at 217. 
sufficient to support the underlease as such. Certainly the result of calling the second lease in this case an interesse tcrmini was very unfortunate. This is now precluded by the statute.01

Of more importance in recent years have been two decisions stressing what has been called the progressive side of the doctrine of interesse termini. In one ${ }^{02}$ it was held that the lessee before entry had a property right that would entitle him to damages if invaded. In the other ${ }^{93}$ it was held that as the intcresse termini in the earlier law was not a mere naked right, but was assignable, it was vested and not obnoxious to the rule against perpetuities even though the lease was not to commence for more than twenty-one years. This result is rather startling, for in principle there would seem to be no more reason for a leasehold commencing more than twenty-one years in the future than for a freehold so commencing. ${ }^{\text {a }}$ Nor would the fact that the old interesse termini was assignable when executory interests and rights of entry were not, necessarily lead to that result. Such interests have since been made assignable without freeing them from the rigors of the rule and it does not follow that the interesse termini, because in this respect it was so much ahend of time, should on that account be made an exception. Coke undoubtedly treated a term by way of remainder as vested so that the lessee in remainder might receive a release, ${ }^{23}$ but in doing so he was distinguishing the term in remainder from an interesse termini. If the doctrine of interessc tcrmini frees all future leaseholds from the rule against perpetuities, that is so much against the doctrine. ${ }^{0}$ Evidently the drafters of the new property acts were of this opinion, for they made void all leases to commence more than twenty-one years in the future. ${ }^{0 r}$

What has been characterized as the progressive side of the doctrine of interesse termini as expounded by Coke, the existence in the lessee before entry of an interest in the land which was something more than a mere naked right and was grantable over and would pass to administrators and executors, ${ }^{\text {DS }}$ has been repeated over and over in American texts and is no doubt law in the United States whether the lease be in proescnti or in futuro. There are no such clear cut cases in the United States, ${ }^{00}$ as in

\footnotetext{
91 Supra notes 73,74 .

92 Gillard v. Cheshire Lines Committee, 32 W'kly Rep. 913 (1884).

${ }^{93}$ MIann, Crossman \& Paulin v. Land Registry, su!pra note 68.

94 Gray makes certain distinctions. Grar, The Rule Agarist PenferurTIES (3d ed. 1915) $\S 320$, n. 5.

85 Co. LITT. $* 270$ a.

96 See 1 Tiffany, Real Property (2d ed. 1920) 604.

97 (1925) 15 Geo. V, c. 20, § 149 (3).

9s Supra at 9.

${ }^{99}$ In the United States such attention as the matter has had has bean
} 
England, ${ }^{100}$ holding that this means that the interesse termini is a right in rem good against all the world, but the significance of the assignability of the interesse termini in making such interest a property right was so fundamental that it must have been as evident to the common lawyers of the United States as it was to the English judges. This is borne out by the remedies given the lessee before entry, as, for instance, against a previous tenant holding over. Trespass in such a case is out of the question, for the holdover tenant is in by right, but in the United States generally, as in England, he has been given ejectment ${ }^{101}$ and in two late cases an action for damages. ${ }^{102}$ There is even authority for giving him the right to summary proceedings. ${ }^{\text {10 }}$

Once the propery right of the lessee before entry was recognized it would seem to have carried possession with it and thus obviated all necessity for an entry, for it was early American doctrine that right or title carried with it possession unless the property was in the adverse possession of another ${ }^{104}$ and this possession, unlike the statutory possession under the Statute of Uses in England, was sufficient to support trespass. ${ }^{105}$ Most of the early American cases announcing this doctrine involved ownership ${ }^{106}$ but the doctrine was applied to lesser interests as well. ${ }^{107}$ So it would seem that in the United States there is no need to resort to the Statute of Uses to avoid the less progressive side of Coke's doctrine of interesse termini. But if resort be had to it the same result would be reached, ${ }^{108}$ for there are but few leases where rent is not reserved if the statement of a consideration be necessary to bring the statute into play. This result is in accord with the authorities, for it is generally agreed that, except where for some reason actual possession is required,

airected towards whether or not an entry is necessary rather than to an analysis of the right before entry.

${ }^{100}$ Supra notes 88, 92.

10136 C. J. $60, \mathrm{nn} .24,25$. But see $i b i d$. n. 29 . See also 1 TIFFANY, LANDLORD AND TENANT (1912) 291, 293. As against the landlord see 36 C. J. 54 , nn. 51, 52.

102 Joels v. Byers, 93 Okla. 90, 219 Pac. 687 (1923); Kokomo Rubber Co. v. Anderson, $161 \mathrm{Ga} .842,132 \mathrm{~S}$. E. 76 (1926). That the courts in the United States have been rather slow to recognize the action for damage, see 36 C. J. 60, n. 36 .

10336 C. J. 60 , n. 33 ; ibid. 634, n. 19 ; 2 TIFFANY, op. cit. supra note 101, at 1736, n. 115. But see 36 C. J. 60, nn. 31, 32; 2 TIFFANY, op. cit. supra note 101, at 1736, n. 117.

104 Bordwell, Disseisin and Adverse Possession (1923) 33 YALE LAW Journat 1, 2.

105 For the American law see Ames, Lectures on Legal History (1913)

229, n. 5; for the English, ibid. 228, nn. 6, 9.

10638 Cyc. 1022, n. 89, 1023, n. 90.

107 Ibid. 1025, n. 4.

108 Maltbie v. Olds, 88 Conn. 633, 92 Atl. 403 (1914); Kokomo Rubber

Co. v. Anderson, supra note 102 . 
actual entry has little significance. ${ }^{100}$ Such significance as it has would seem to be a matter of terminology and not a matter of substance. It is still said that prior to entry, the right of the lessee is an interest and not an estate ${ }^{110}$ although exception is made even to this where the Statute of Uses applies.

The gift of actions to the second lessee against the hold-over tenant does not necessarily deny similar actions to the landlord. ${ }^{121}$ Unless the landlord is bound to give the second tenant possession, he does not have need of such actions, but where as in several states the English rule is followed ${ }^{112}$ and the landlord is bound to give the tenant possession, his right of action against the first tenant necessarily follows. In some way the proper protection of the landlord who makes a first lease and then a second lease to follow immediately after the first, is assumed to be tied up with the doctrine that the second lease in such a case is a mere interesse termini.113 The phrase is undoubtedly useful in distinguishing a concurrent lease from one which is to commence after the other terminates, but it does not seem likely that the abolition of the doctrine of interesse termini in England will affect the protection hitherto given there to landlords. If this is so, the phrase interesse termini may well be dropped altogether and the term reversionary lease used exclusively in such a case instead. ${ }^{114}$ Certainly in a case like Lewis v. Baker ${ }^{215}$ the landlord would be much better protected with the abandonment of the notion of interesse termini if such notion was responsible for the result in that case. There seems to be no case exactly like Lewis $v$. Baker in the United States ${ }^{126}$ and it is to be hoped that there will not be. Nor should considerations of the old interesse termini have great weight in the application of the rule against perpetuities to future leases. ${ }^{112}$ But if terminology should have

10936 C. J. 50, n. 66; WOOD, LANDLORD AND TENANT (1881) 358; 1 UNDERHILL, LAANDLORD AND TENANT (1909) 354.

110 See cases cited 35 C. J. 953, nn. 32, 33; 1 TIFFANY, op. cit. supre note 101 , at 291, n. 672 .

11136 C. J. 634, nn. 16, 17, 18.

11236 C. J. 52, nn. 13, 14. For the rule followed in perhaps a greater number of American jurisdictions, see ibid. n. 12.

113 See Lewis v. Baker, supra note 88.

114 For the use of the terms "concurrent lease" and "lease in reversion" see 1 TIFFANY, op. cit. supra note 101, at 871.

115 Supra note 88.

116 Perhaps the closest case to Lewis v. Baker is that of Stewart v. Long Island R. R. Co., 102 N. Y. 601, 8 N. E. 200 (1886). The decision was in line with Lewis v. Baker but the case is very distinguishable and in his dissenting opinion Finch, J., supposed such a case as Lewis v. Balier and argued from what seemed to him to be the only possible result in such a case, to the principal case.

${ }^{117}$ But see Abbot, Leases and the Rule against Pcrpetuitics (1018) 27 YaLe LaW Journal 878. 
any weight in such a matter, the classification of the future lease as an interest rather than as an estate would suggest the executory interests, which are undoubtedly subject to the rule, rather than present estates of future enjoyment, which are not.

\section{NEW LEASEHOLD CODE}

A great number of provisions affecting leaseholds in what Mr. Topham ${ }^{118}$ says "might be called a Leasehold Code" are contained in sections 139 to 154 of the Law of Property Act, 1925.119 Except for the abolition of the doctrine of interesse termini and the requirement that future leases should not be limited to commence after 21 years, ${ }^{120}$ these provisions are in large part restatements of the statutory reforms of the law as to leaseholds of the nineteenth century. These reforms seem to have justified themselves, for there is no tendency to revert to the older law. On the contrary much of that legislation is carried further by the new legislation.

\section{THE MERGER OF REVERSIONS}

The law of merger was one of the most technical and arbitrary parts of the old conveyancing. All of the scholastic logic of the time of Coke was here seen at its worst.121 An example of this was the rule that if $A$ let the premises to $B$ and $B$ sublet them to $C$, and then $B$ surrendered to $A$ or $B$ acquired $A$ 's estate, $B$ 's reversion was drowned and carried to destruction with it its incidents, such as the right to collect rent from $C .^{122}$ This rule ${ }^{123}$ thus operated for $C$ 's benefit, but it was not allowed to work to his detriment. ${ }^{124}$ His estate continued. ${ }^{125}$ And if, instead of an estate, $C$ had had a rent-charge, the rent-charge would have continued notwithstanding the merger. ${ }^{128}$ A case of particular hardship was where the intervening tenant, $B$, would surrender for

118 Topham, The Law of Property Acts (1926) 61 LaW Journal 106, 108. 119 (1925) 15 Geo. V, c. 20.

120 Supra note 97.

1213 PRESTON, op. cit. supra note 71, is the authority cited everywhere on the law of merger. When it is considered that his authorities were largely from the time of Coke-and therefore that in citing Preston one is really going back to the days of Coke and before the rise of a settled system of equity, one is tempted to believe that most of Preston's learning is obsoleto as well as ancient, and there is much to justify the belief.

1223 ibid. 129 et. seq.

123 The rule is usually associated with the case of Webb v. Russell, 3 Term R. 393 (1789), but it goes back at least to Thre'r v. Barton, Moore 94 (1570).

${ }^{124}$ As to this diversity, see Co. LiTT. $* 338 \mathrm{~b}$.

1253 PRESTON, op. cit. supra note 71 , at 447 et. seq., 556.

226 Ibid. 447. 
the purpose of taking a new lease. The undertenant might continue without the payment of rent. ${ }^{127}$ This case was met by the Landlord and Tenant Act, $1730,{ }^{128}$ but the general rule as to the extinction of the rent along with the merger of the reversion continued until 1844.129 A more effective provision was passed the following year ${ }^{130}$ and is now reenacted as section 139 of Law of Property Act, 1925.131 It provides that

"where a reversion expectant on a lease of land is surrendered or merged, the estate or interest which as against the lessee for the time being confer's the next vested right to the land, shall be deemed the reversion for the purpose of preserving the same incidents and obligations as would have affected the original reversion had there been no surrender or merger thereof."

The earlier English legislation has been adopted ${ }^{132}$ in at least two states ${ }^{133}$ in this country and the later in at least one. ${ }^{134}$ The lack of a more general adoption does not, however, indicate any liking for the old English rule. On the other hand, the idea that a sublessee should be allowed the advantages of his sublease without paying therefor has, from the time of Chancellor Kent, been denounced as "mischievous" and "inequitable." 135 Courts have repeated the old rule as if it were law in the United States, ${ }^{123}$ but they have gotten away from its consequences ${ }^{237}$ and one court

\footnotetext{
127 Ibid. 138.

128 (1731) 4 Geo. II, c. $28, \S 6$.

129 (1844) $7 \& 8$ Vict. c. $76, \S 12$.

130 (1845) 8 \& 9 Vict. c. $106, \$ 9$.

131 Supra note 119.

1321 Stimson, AN. StaT. Law (1886) § 2063.

133 N. Y. Cons. Laws (Cahill, 1923) c. 51, \$ 226; N. J. Comp. Stat. (1910) $3075, \S 25$.

134 Ml. Rev. Stat. (Cahill, 1927) c. 30, $\$ 42$.

$1354 \mathrm{KENT}$, CoMm. 103 . This dislike for the rule did not originate with Chancellor Kent. In Webb v. Russell itself, supra note 12\%, Lord Kenyon said: "The defence which is made is of a most unrighteous and unconscientious nature" Late American authorities criticising the rule are Hessel v. Johnson, $129 \mathrm{~Pa}$. 173, 18 Atl. 754 (1839); Appleton v. Ames, 150 Mass. 34,22 N. E. 69 (1889); MICDonald v. May, 96 Mo. App. 296, 69 S. W. 1059 (1902).

136 Bailey v. Richardson, 66 Cal. 416, 5 Pac. 910 (1885); Krider v. Ramsay, 79 N. C. 354 (1878).

${ }_{137}$ A notable case is Beal v. Boston Car Spring Co., 125 Irass. 157 (1878), where a clause to the effect that the surrender should be without prejudice to the sublessees was held equivalent to the separation of the rent from the reversion and its assignment to the superior landlord. In Appleton v. Ames, supra note 135, there had been breach of conditions in the superior lease and the sublessee had paid rent to the superior landlord. He was held to be liable for rent as a tenant at will. In MIcDonald v. Miay, supra note 195, the sublessee had paid rent to the superior landlord and it was held that this amounted to an attornment, and that he was liable for ront for the entire period of the sublease. In two California cases, Bailey v. Richard-
} 
has definitely rejected the rule itself..$^{138}$ It runs counter to the equitable doctrine that merger will not operate contrary to the intention of the parties ${ }^{138}$ and it is the equitable doctrine of merger rather than the old common law doctrine that would seem to have been adopted in the United States. ${ }^{140}$ It is not too much to expect that the lead of the Pennsylvania courts in definitely rejecting what may be called the rule of $W e b b v$. Russell ${ }^{141}$ will have a general following.

\section{COVENANTS RUNNING WITH THE LAND}

The modern law of covenants running with the land commences with the statute of (1540) $32 \mathrm{Hen}$. VIII, c. 34 and Coke's report of Spencer's Case. ${ }^{142}$ Beyond these lie surmise and assumption. ${ }^{143}$ Both the statute and the report dealt with leases. The one was concerned with the running of the burdens and benefits of covenants with reversions, the other with the running of these with the estate of the lessee. Neither concerned the running of covenants with land where the relationship of landlord and tenant did not exist. And where such relationship does not exist and covenants for title are not involved, the development of the law in England has been very meagre. ${ }^{144}$ This is

son, supra note 136, and Standard Oil Co. v. Slye, 164 Cal. 435,129 Pac. 589 (1913), it was held that where the superior landlord had collected rent from the sublessee, the latter might sue him on the covenants in the sublease as assignee of the reversion. See also 1 TIFFANY, op. cit. supra note 101, at 99. 138 Hessel v. Johnson, supra note 135.

1392 PoMeroy, Equity JURISPRUDENCE (4th ed. 1918) § 786 et. seq.

140 In 7 Ann. Cas. 702, note, it is said: "The doctrine of legal merger is now practically extinct both in England and in the United States, equitable principles being generally applied by the courts of both countries. In the foregoing cases cited as supporting the legal doctrine of merger, the doctrine is stated but the equitable doctrine is applied." This statement is adopted in 10 R. C. I. 666 .

14 See supra note 123.

1425 Co. 16 a (1583). For the lack of medieval authority on the matter, see 7 Holdsworth, A History OF ENgLish LAW (3d ed. 1922-26) 288.

${ }^{143}$ Perhaps the most conspicuous assumption is that covenants running with the land had their origin in implied warranties. See Sims, Covenanis WHICH RUN WITH LAND (1901) 32, 33, 45, 57, 58. As to the questionableness of this assumption, see Clark, The Doctrine of Privity of Estate in Connection with Real Covenants (1922) 32 YALE LaW Journat, 123, 140, n. 80 .

144 Sims, op. cit. supra note 143 , at 135, says: "Strangely enough, however, while this running of benefits has been accepted, there is not, it is thought, a single English decision that such a benefit will run until comparatively late days. There is no lack of them in America, it is true, but at the same time the American courts were free in holding that burdens of covenants would run as well. The editor of Smith's Leading Cases asserts as his conclusion that benefits have been established as running, but he cites no cases but cases of covenants for title and cases of leases, from the cases in Norman French to the rise of the equitable doctrine of Tulk v. Moxhay." 
explicable in later years by the great development of the law of equitable restrictions starting with Tulk v. Moxhay. ${ }^{\text {145 }}$ But to return to Coke's report of Spencer's Case. Though concerned with the estate of the lessee, it has affected the law as to the running of covenants with reversions, and even the law of the running of covenants where no lease is involved. It established a general principle that collateral covenants do not run and raised difficulties, not confined to leases, about the running of covenants with regard to things not in esse where the intention to bind the assigns is not expressed.

The Real Property Commissioners of a century ago thought the restrictions put on the running of covenants in leases by Spencer's Case were artificial and that all covenants in leases entered into by lessees "of whatever nature and for whatever purpose, unless an intention to the contrary be expressed, or is to be inferred from the instrument, should be binding on every assignee of the term." ${ }^{140}$ The new legislation has not gone that far. The requirement that the covenant shall "touch and concern the land" is still retained ${ }^{147}$ in the qualification that the covenant or provision shall have "reference to the subject matter" ${ }^{103}$ of the lease. Whether the subject matter of the covenant be in existence or not, however, is made immaterial..$^{140}$ It is expressly declared that no technical expression is necessary to malie benefits run ${ }^{150}$ and in the case of benefits the covenant is deemed to be made with the covenantee and his successors in title, ${ }^{35}$ and in the case of burdens with the covenantor and his successors in title..$^{152}$ In the case of burdens this is so "unless a contrary intention is expressed" 153 and although no such qualification is made in the case of benefits, it would seem that such qualification must be implied. ${ }^{154}$

145 2 Phil. 774 (1848). The extent to which the doctrine of equitable restrictions has superseded the lav of covenants running with the land where neither leases nor covenants for title are involved has been stressed by English more than by American writers, but despite the running at law of burdens as well as benefits in the United States, the difrerence between the relative importance of the two doctrines in the two countries rould scem to be one of degree.

146 THIRD REPORT (1832) 46.

${ }_{147}$ Barnes v. City of London Real Property Co. [1918] 2 Ch. 18, 33.

148 (1925) 15 Geo. V, c. 20, \$\$ 141, 142.

149 Ibid. § 79 (1).

$150 \mathrm{Ibid}$ \$ 80 (3).

151 Ibid. § 78 (1).

152 Ibid. § 79 (1).

153 Ibid.

154 SrMS, op. cit. supra note 143 , at 116, has asserted that if covenants, at least in leases can run they must run, but his only authority is to the contrary. And see 2 TIFFANY, op. cit. supra note 96, at 1415; 1 TrFFas;, op. cit. supra note 101, at 892; Abbot, Covenants in a Lcase Which Run with the 
These statutory provisions are not contained in the so-called Leasehold Code ${ }^{155}$ but in Part II of the Law of Property Act, 1925, dealing with contracts, conveyances and other instruments. ${ }^{150}$ They are of general application and were designed, as Mr. Lightwood puts it, "to enable the draftsman to use legal shorthand." 157 Where covenants will run with the land if the successors in title of the covenantee or covenantor are mentioned, they provide that the covenants shall run without such express mention even though the subject-matter of the covenant may not be in existence when the covenant is made. ${ }^{158}$ They do not make the burden of covenants to do affirmative acts run where such burdens would not have run under the previous law, if successors in title had been mentioned. There would therefore seem to be little reason for the alarm felt by conveyancers that these provisions have changed the accepted law in England that the burden of affirmative covenants does not, either in law or equity, run with the land except in leases. ${ }^{150}$ The provision with regard to covenants to do acts with regard to things not in esse would seem to have been given its proper place in the part of the statute devoted to legal shorthand even though its only application be to leases.

The statute of Henry VIII ${ }^{160}$ making covenants run with the reversion was modernized and extended by the Conveyancing Act, 1881. ${ }^{161}$ The former applied to "indentures" and thus required a seal. ${ }^{162}$ The latter had no such restriction and has been held to apply to written but not oral leases. ${ }^{103}$ And whereas the former made covenants run to and against the assigns of the lessor, by the latter the covenants or provisions in the lease are annexed to, and made to run with, the reversion or a part thereof, as such. ${ }^{164}$ Furthermore the one entitled to the income of the leased land is given the right to enforce the provisions of the

Land (1921) 31 YaLe LaW Journal 127, 143. The effect of both sections 78 and 79 seems to be that if covenants can run they are presumed to run unless the contrary is expressed.

155 Supra note 118.

156 The Leasehold Code is Part V.

157 Lightwood, Covenants Running with the Land (1925) 60 LAW JourNaL $812,813$.

158 See supra note 149.

159 See Lightwood, up cit. supra note 157, at 800, 812; Topham, op. cit. supra note 118, at 106.

160 (1540) 32 Hen. VIII, c. 34.

101 (1881) 44 \& 45 Vict. c. $41, \S \S 10,11$.

162 Standen v. Chrismas, 10 Q.B. 135 (1847).

163 Blane vi Francis [1917] 1 K.B. 252; Cole v. Kelly [1920] 2 K.B. 106. 164 Supra note 161. 
lease. ${ }^{165}$ As pointed out by a contemporary writer of great discrimination, this change of formula made great inroads into, if it did not altogether get rid of, the old requirement of privity of estate, ${ }^{166}$ whether between the lessor and lessee, ${ }^{367}$ or between the lessor and those subsequently entitled. ${ }^{\text {Ins }}$ However, no similar relaxation of the requirement of privity of estate was made as to those holding under the lessee, ${ }^{160}$ so that the underlessee ${ }^{150}$ and the equitable assignee of the lease ${ }^{171}$ are still protected from the obligations of the lease by the doctrine of privity of estate except in so far as they are affected by the equitable doctrine of notice.1:2 These changes of the Conveyancing Act, 1881, are incorporated into the Law of Property Act, 1925.173

The Conveyancing Act, $1911,{ }^{174}$ allowed the one entitled to the income from leased land to enforce a condition for a breach occurring before he became so entitled unless the breach had been released or waived before the transfer to him. It made the right to enforce the forfeiture run with the reversion. ${ }^{17}$ This was extended by the Law of Property Act, 1925, so as to malie the right to accrued rent and to sue on broken covenants run also. ${ }^{176}$

The law as to the running of the benefits and burdens of covenants with reversions is not as clearly defined in the United States as it is in England, but there would seem to be no question but that it has progressed at least as far as the statute of Henry VIII. That statute was in furtherance of the common law, was

165 Ibid. $\$ 10$.

166 (1887) 31 SoL. J. 229. See also Lightwood, op. cit. supra note 157, at 801; Behan, Covenants Afrecting Land (1924) 101.

${ }_{107}$ Thus a covenant made by a mortgagor in possession was enforced by the mortgagee on going into possession. Miunicipal Permanent Investment Building Society v. Smith, 22 Q. B. D. 70 (188s), although a like situation in Webb v. Russell, supra note 123, had been the occasion for Lord Kenyon's famous pronouncement that "it is not sufficient that a covenant is concrrning the land, but, in order to make it run with the land, there must be a privity of estate between the covenanting parties." See also Wilson v. Queen's Club [1891] 3 Ch. 522.

168 In Turner v. Walsh [1909] 2 K.B. 484, the assignee of a reversion who had mortgaged the same but whose mortgagee had not gone into possession was allowed to recover damages for a breach of the covenant to repair notwithstanding the legal title in the mortgagee.

${ }_{169}$ Lightwood, op. cit. supra note 157, at 801.

170 BEHAN, op. cit. supra note 166 , at 87 .

171 Ibid. 70.

172 Ibid. 145; Cheshire, MIodern Law of Real Proferty (1925) $21 \%$.

$173 \S \S 141,142$.

17ะ (1911) $1 \& 2$ Geo. V, c. $37, \S 2$.

175 In Davenport v. Smith [1921] $2 \mathrm{Ch}$. 270, the court showed itself very ready to find a waiver of the forfeiture. But see Atkin v. Rose [1929] 1 Ch. 522.

176 (1925) 15 Geo. V, c. $20, \S 141$ (3). See op. cit. supra note 7, at 172. 
of general application and, except in so far as it may not have gone far enough, suited to our conditions. In the absence of evidence to the contrary, therefore, it may be taken to be part of the common law in the United States. ${ }^{177}$ It has been superseded by similar statutes in a good many states ${ }^{178}$ and has been assumed or declared not to be part of the common law in two others, ${ }^{178}$ but the principles adopted in these two states go much farther than the statute itself. ${ }^{180}$ The running of covenants with the interest of the lessee has been little affected by direct legislation ${ }^{181}$ and goes back to Coke's report of Spencer's Case. ${ }^{182}$ The question remains as to how far the progress made in England during the last half century has been realized in the United States.

The restriction of the statute of Henry VIII to "indentures of lease" 183 was more or less incidental, although seals were mentioned in the preamble. All "conditions, covenants, or agreements" in the lease were to run. Only in the New Jersey statute ${ }^{184}$ is there a like restriction to "indentures of lease" and

${ }^{177}$ See the authorities cited in 1 TIFFANY, op. cit. supra note 101, at 884; L.R.A. 1915 C, 211-212, annotation.

${ }^{178}$ See Sims, op. cit. supra note 143 , at 74-77; 1 TrFfaNY, op. cit. supra note 101 , at $883-884$.

179 Baldwin v. Walker, 21 Conn. 168, 181 (1851) ; Crawford v. Chapman, 17 Ohio 449 (1848).

180 In Baldwin v. Walker, supra note 179, at 181, the court said: "An assignee of the lease may sue in covenant and is liable in the same form of action. There can be no sufficient reason why the assignee of a lessor should stand differently related to other parties to the lease and especially why ho may not sue in covenant for rent falling due in his time." In Masury v. Southworth, 9 Ohio St. 340, 346 (1859), the court said: "If the covenant bo assignable in equity, so that an action might have been maintained in tho name of the assignor, or relief obtained by a suit in equity, our code of civil procedure operates upon the remedy, even more extensively than the statute of $32 \mathrm{H}$. VIII, c. 34 . For whether the covenant be collateral, or inhoro in the land, if it be assigned, the assignee not only may, but, as the party beneficially interested, must sue in his own name."

In Smith v. Harrison, 42 Ohio St. 180, 184 (1884) the court took ono step further and made the covenant run irrespective of any assignment of tho covenant itself. It said: "Her right to the rent arises from her ownorship of the reversion. The covenant for rent by the lessor came to her by succession to the lessor's estate. It was a covenant that passed with the land, and although not made with her, it was made for her benefit. Henco her right of action on the covenant under our code, though the statute of 32 Henry VIII be not in force in this state." And see Broadwell v. Banks, 134 Fed. 470, 475 (D. Mo. 1905).

181 However some of the statutes referred to supra note 178 cover the running of covenants with the lessee's interest as well as with the reversion. 182 Supra note 142.

183 Supra note 160.

note 101, at 896, states that Mississippi statute adopts the langunge of

184 N. J. Comp. Stat. (1910) p. 1538, §§ 16, 17. 1 TIFFANY, op. cit. supra note 101 , at 896 , states that the Mississippi statute adopts the langunge of 
that statute is over a century old. The other statutes in the United States are not restricted to leases under seal and some of the statutes are broad enough to include oral leases. ${ }^{185}$ Probably these statutes are fairly representative of the general law. In those states where the statute of Henry VIII is part of the common law, it is its spirit that is binding and not its letter, ${ }^{280}$ and its spirit is better shown by the express inclusion of "agreements" as well as "covenants," than by the incidental reference to "indentures of lease." If the spirit of that statute is not enough to make agreements in written leases not under seal run, there are the statutes like that in Ohio which in effect make choses in action assignable ${ }^{287}$ and which either supplement the English statute ${ }^{185}$ or, as in Ohio, take its place. These statutes would make benefits, rather than burdens, run with leases, but the principle of the statute of Henry VIII that where the benefits run, the burdens should run also, is so strong that it is hardly conceivable that any court would make the benefits or agreements in written leases run, but not the burdens. ${ }^{150}$ No court in this country, it is believed, has denied the running of a contract in a lease because the latter was not under seal, and it would be a distinct shock if one should. To make the provisions of written and even oral leases run with the lease and the reversion is not going nearly so far as making the burden of stipula-

the English statute making it applicable to "indentures of lease" only, but this is evidently a mistake. See MIiss. Code (1906) $\$ \$ 2877,2878$.

${ }^{185}$ For example, there would seem to be nothing to restrict the application of the following provision, which is in force in Indiana, Kansas and Olilahoma, to written leases. "Alienees of lessors and lessees of land shall have the same legal remedies as their principals." 3 Ind. Ann. Stat. (Burns, 1926) § 9550; Kans. Rev. Stat. Ann. (1923) 67-516; Olla. Comp. Stat. Ann. (Burns, 1921) § 7355 .

186 This would seem true of all the old statutes that have been adopted as a part of the common law in the United States. As integral parts of our common law, they have not the exceptional imperative character of our own statutes. They have been adopted in principle and not in letter. They partake of the vitality and progressive adaptability of judge-made law rather than of the sterility and rigidity of legislative enactments.

187 Supra note 180.

188 See 1 TIFFANY, op. cit. supra note 101, at $885, \mathrm{n} .98$, for authorities under the older law where the principle that the assignee could sue in the assignor's name was used to supplement the statute. Under the modern statutes, the assignee can sue in his own name and, as it is believed that the effect of these statutes is to make choses in action really assignable, the difficulty under the old law referred to by Tiffany of a suit by a second or third assignee disappears. For a discussion of the running of contracts in parole leases, see Sims, op. cit. supra note 143, at 87-89.

189 Sims, op. cit. supra note 143, at 89, says: "But whatever difficulty may be encountered in the explanation of the running of benefits in parole leases, in the carrying of burdens, it is believed no difficulty is encountered." His explanation is the primary obligation of the land and the relationship of principal and surety. 
tions in grants in fee by deeds poll run, ${ }^{100}$ and yet such is the weight of authority in this country. ${ }^{191}$

Such statutes as there are in the United States follow the language of the statute of Henry VIII in making the covenants in the lease run to and against the assigns of the lessor, rather than the language of the Conveyancing Act, 1881, which makes the covenants run with the reversion as such..$^{102}$ Nor does there seem to be any provision that the one entitled to the income may enforce the covenants. ${ }^{193}$ Privity of estate between the lessor and those subsequently entitled to the reversion would therefore still seem to be a prerequisite to the running of covenants with the reversion in the United States. ${ }^{104}$ However, this is of the less importance because of (1) the absence of statutes giving the limited owner power to make leases binding the ultimate reversion, (2) the prevalence, especially in the west, of legal title in the mortgagor, and (3) the probability of the enforceability of the covenants of a sub-lease by and against the holder of the ultimate reversion where under the older common law there would have been a merger of the sub-reversion.195 Moreover, at least in one case, the equitable assignee in possession of the rent was held entitled to all the rights of a landlord. ${ }^{100}$ And the cases are quite numerous where an equitable assignee of the lessee's interest has been held on the covenants in the lease. ${ }^{107}$ Even one in possession of the leased premises, though neither legal nor equitable assignee of the lessee, has been so held. ${ }^{198}$ But this does not seem to have been carried so far as to make the sub-lessee liable on the lessee's covenants. ${ }^{109}$

The situation that called forth Lord Kenyon's pronouncement that for convenants to run there must be privity of estate between the covenanting parties, that is, the case of the mortgagor who makes a lease and then assigns, ${ }^{200}$ presents no difficulty in those states where the mortgagor has the legal title. And in states where the mortgagor does not have legal title even though the lack of title appear on the face of the lease, ${ }^{201}$ the conventional

190 See Srms, op. cit. supra note 143 , at 188-195.

191 Ibid.; 2 TIFFANY, op. cit. supra note 96, at 1402.

192 Supra note 164.

${ }^{193}$ Supra note 165.

194 See 1 TIFFANY, op. cit. supra note 101, at 902.

195 See THe Merger of Reversions, supra at 16.

196 MrcLean v. Spratt, 19 Fla. 97 (1882), cited in 1 TiFfaNY, op. cit. supra note 101, at 902 , n. 205. This case, however, did not directly involve the running of covenants.

197 See the cases cited in ibid. $972, n .354$.

198 Ibid. 973, n. 355.

190 Ibid. 1000. But that he is subject to equitable restrictions in the head lease, see ibid. 810, nn. 98, 823.

200 See supra note 167.

201 There is a question in England as to whether the rule of estoppel on

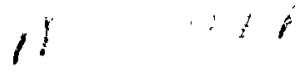


estoppel of the tenant to deny his landlord's title would appear broad enough in the United States to carry the covenants with it. 202

The statutory inference in England that covenants that can run will run unless such intention is rebutted ${ }^{003}$ is probably the general rule with regard to covenants in leases in the United States, ${ }^{204}$ and although there is little authority on the subject, it is at least arguable that such is the law where a covenant is contained in a grant of land in fee..05 Nor are any technical words necesary to make a convenant run. ${ }^{006}$

In a few states the old requirement of Spencer's Case that there must be express words to make a covenant run where it concerns something not in existence $=07$ is still law. Thus something very much like that rule was incorporated into David Dudley Field's draft code ${ }^{\text {sos }}$ and found its way into the codes of California, ${ }^{209}$ Montana, ${ }^{210}$ and North ${ }^{211}$ and South Dakota..12 In Alabama, ${ }^{213}$ Maryland, ${ }^{214}$ New York, ${ }^{215}$ Tennessee ${ }^{219}$ and Texas ${ }^{21 \tau}$

the tenant prevails so as to make covenants run when the lack of a legal estate appears in the lease, but this has been held immaterial in an action to try the validity of a distress and the earlier English cases involving covenants and ejectment stand on narrow ground and are of doubtful authority. See BIGELOW, Estoppes (6th ed. 1913) 395, 582; 1 TIFFuir; op. cit. supra note 101, at 896 .

${ }^{202}$ In Tilyou v. Reynolds, 108 N. Y. 558, 563, 15 N. E. 534,536 (1888), the court adopts the reasoning of the later English cases, and it is the reasoning of these cases that is favored by both Bigelow and Tifiany, supro note 201.

203 Supra at 19.

204 See Abbot, op. cit. supra note 154, at 144 .

2052 TIFFANX, op. cit. supra note 96, at 1415.

206 See SiMs, op. cit. supra note 143, at 206.

207 Supro at 19.

208 A Draft For a CruL COde for the State of New York (1862) § 695.

209 Cal. Civil Code (Deering, 1923) § 1464; Bailey v. Richardson, surno note 136.

210 Mont. Rev. Codes (Choate, 1921) § 7420.

211 N. D. Comp. Laws (1913) \$ 5789.

212 S. D. Rev. Code (1919) § 747.

213 Etowah Mrining Co. v. Wills Valley Irining Co., 121 Ala. 672, 25 So. 720 (1899).

211 IId. \& Pa. R. R. v. Silver, 110 IId. 510, 73 Atl. 297 (1909).

215 In the absence of any expression on the matter from the Court of Appeals in over seventy years, perhaps the statement in the text is too favorable to the existence of the old rule. The old cases which seemed to have established the old rule, in chronological order, are: Lamctti v. Anderson, 6 Cow. 302 (N. Y. 1826); Thompson v. Rose, 8 Cow. 260 (N. Y. 182S); Verplanck v. Wright, 23 Wend. 506 (N. Y. 1840); Allen v. Culver, 3 Den. 284 (N. Y. 1846); Tallman v. Coffin, 4 N. Y. 134 (1850); Coffin v. Tallman, 8 N. Y. 465 (1854). But in Duffy v. N. Y. \& H. R. R. R., a Hilton 496 (N. Y. 1859), the court of Common Pleas said that the distinction could not "now be said to exist." In Matter of Coatsworth, 97 App. Div. 295, 55 N. Y. Supp. 753 (4th Dept. 1899), the court found an intention that the 
the courts seem pretty well committed to the old rule. In Illinois the matter may be said to be in doubt..218 The rule has been severely condemned in Pennsylvania, ${ }^{219}$ has been avoided in Massachusetts ${ }^{220}$ and New Jersey, ${ }^{221}$ and definitely rejected in Iowa, ${ }^{22 z}$ Ohio, ${ }^{223}$ Oregon, ${ }^{224}$ and Wisconsin. ${ }^{225}$ The whole trend of modern

covenant should run and in Douglaston Realty Co. v. Hess, 124 App. Div. 508, 108 N. Y. Supp. 1036 (2d Dept. 1908), that the covenant related to something in being. In Ovington Bros. v. Henshaw, 47 Misc. 167, 03 N. Y. Supp. 380 (Sup. Ct. 1905), Gaynor, J., at special term, applied the old rule. In Sammis v. Town of Huntington, 104 Misc. 7, 171 N. X. Supp. 965 (Sup. Ct. 1918), the old authorities were affirmed but express words found.

${ }^{216}$ Aside from the early New York cases, the carly Tennessee cases have probably been cited more than any others in support of the old rule. The leading case is Bream v. Dickerson, 2 Humph. 126 (Tenn. 1840). This was followed by Brooks v. Smith, Thompson's Tenn. Cases 226 (1860), and .Cronin v. Watkins, 1 Tenn. Ch. 119 (1873). In Doty v. Railroad, 103 Tenn. 564,53 S. W. 944 (1899), the court seemed prepared to abandon the old rule, but in Cicalla v. Miller, 105 Tenn. 255, 58 S. W. 210 (1900), Bream v. Dickerson was directly in point and was followed. And see Carnegie Realty Co. v. Railroad, 136 Tenn. 300, 189 S. W. 371 (1916).

217 Gulf, C. \& S. F. Ry. v. Smith, 72 Tex. 122, 9 S. W. 865 (1888).

218 One of the cases most frequently cited in support of the old rule is Hansen v. Meyer, $81 \mathrm{Ill}$. 321 (1876), and Mr. Leesman thinks that it still represents the law in Illinois, at least as to leases. See Leesman, Covenants Running with the Land in Illinois (1920) 14 ILI. L. Rev. 395, 398-400, 408. This may be so and Illinois may repeat the experience of Tennessee, but Purvis v. Shurman, 273 IIl. 286, 112 N. E. 679 (1916), heartily disapproves of the distinction in Spencer's Case and restricts it at any rate to cases to which it is directly applicable. Thus the rule was not applied in Dorsey v. St. L., A. \& T. H. R. R., 58 Ill. 65 (1871), where if applicable at all, it would have been applied in the case of a natural person, and in Brockmeyer v. Sanitary District of Chicago, 118 Ill. App. 49 (1905), express words woro held unnecessary to make benefits run.

219 Bald Eagle Valley R. R. v. Nittany Ry., 171 Pa. 284, 33 Atl. 239 (1895). See also Kelly v. Nypano R. R., 23 Pa. Co. Rep. 177, 184 (1900). 220 Peters v. Stone, 193 Mass. 179, 79 N. E. 336 (1906); Hollywood v. First Parish in Brockton, 192 Mass. 269, 78 N. E. 124 (1906).

221 Conover v. Smith, 17 N. J. Eq. 51 (1864); Woodruff v. Trenton Wator P. Co., 10 N. J. Eq. 489, 505 (1856); Winfield v. Henning, 21 N. J. Eq, 188 (1870).

222 Sexauer v. Wilson, 136 Iowa 357,113 N. W. 941 (1907). Seo also Frederick v. Callahan, 40 Iowa 311 (1875).

${ }^{223}$ Masury v. Southworth, supra note 180 , at 350 , is the leading caso in the United States in favor of converting the rule in Spencer's Case into a non-technical rule of intention. It was apparently overlooked in Newburg Petroleum Co. v. Weare, 44 Ohio St. 604, 9 N. E. 845 (1887), but was roaffirmed in Pittsburg v. Bosworth, 46 Ohio St. 81, 18 N. E. 533 (1888\%).

224 Brown v. Southern Pacific Co., 36 Or. 128, 58 Pac. 1104 (1899). The subsequent case of Duester v. Alvin, 74 Or. 544, 145 Pac. 660 (1915), incidentally cites the Brown case as requiring the assigns to be named wheroas the contrary opinion was expressed in that case after a thorough-going discussion. This is the more surprising in that the opinions in the two cases were written by the same judge. The principle of the Brown Case was affirmed in Pearson v. Richards, 106 Or. 78, 86, 211 Pac. 167, 170 (1922). 
decisions is against the relevance of the existence or non-existence of the subject matter of the covenant. Probably no court would hold that the word "assigns" is a word of art without which a covenant as to a thing not in cssc could not run.226 Probably few, if any, courts which recognize the distinction at all would go further than let the non-existence of the subject matter raise a presumption against the running of the covenant.2: It is probable that no one would deny that the distinction is the scholastic product of a by-gone age.228 Furthermore a decided majority of the cases within the last fifty years are unfavorable to the distinction. ${ }^{223}$ Reason and the weight of authority would therefore seem to concur that in the United States at the present time the non-existence of the subject matter of the covenant is irrelevant to the running of the covenant with the land, unless it be to preclude any presumption of running that might exist had the subject matter been in existence. 230

The recent change in the law in England providing for the running with the reversion of acrued rent and the right to enforce covenants for previous breaches ${ }^{232}$ is a distinct innovation and would be such in the United States ${ }^{232}$ although there is some authority here for the running of such rights of action with the fee in the case of covenants for title. ${ }^{33}$ Where the loss or damage has been suffered by the previous holder of the reversion, however, it would seem that he should be the one to recover unless he has meant to pass this right on to his successor. Ordinarily it would seem that such intention would be lacking.:-s

(To be continued)

225 Ecke v. Fetzer, 65 Wis. 55, 26 N. W. 266 (1886). The earlier case of Hartung v. Witte, 59 Wis. $285,18 \mathrm{~N}$. W. 175 (1884), was to the contrary.

${ }^{226}$ See Sexauer v. Wilson, supra note 222 , and Abbot, op. cit. supra note 154 , at 146 .

227 Once get away from the necessity of the word "assigns" and the transition is easy to allowing the intention that the covenant should run to be gathered from the entire instrument as urged by MIr. Abbott, op. cit. apro note 154 , at $143-146$.

228 This is stated nowhere more forcibly than in Bald Eagle Valley R. $R$. v. Nittany Ry., supra note 219 , at 294 .

229 See an able note in 14 I. R. A. (N. S.) 185 (1908). The writer of the note points out that in many cases the distinction has been overlooled entirely. The tendency against the old rule has been accelerated by this note.

230 See ibid.; 7 R. C. L. 1100; Abbott, op. cit. supra note 154, at 146; Clark, op. cit. supra note 143 , at 123,124 . But the old rule is given as still the general law in 1 TrFaNY, op. cit. supra note 90, at 182, and $35 \mathrm{C}$. J. 1188.

231 Supra at 21.

2321 TIFFANY, op. cit. supra note 101, at 899.

233 See 2 TIfFany, op. cit. supra note 96, at 1721, nn. 64, 65.

234 See supra note 232 . 